\title{
Former Supreme Court justice blasts minimum sentences for marijuana offenders
}

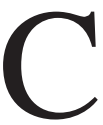

anada's new mandatory minimum sentences for drug offenders are based on "very bad criminal law policy" and constitute a threat to public health as well as the concept of judicial proportionality, former Supreme Court of Canada Justice Louise Arbour says.

The law should, and almost certainly will, face a justifiable constitutional challenge, Arbour adds of the omnibus crime legislation, Bill C-10, which received royal assent in March (www.parl.gc.ca/HousePublications /Publication .aspx ?Docid $=5465759$ $\&$ file $=4$ ).

Forcing judges to impose minimum sentences for drug offences endangers the legal precept of proportionality, under which judges must tailor the level of punishment to the severity of the crime, adds the former United Nations high commissioner for human rights and former chief prosecutor of the International Criminal Tribunals for Rwanda and the former Yugoslavia.

"Each case is very contextual," argues Arbour, who served on the Supreme Court from 1999-2004 and is currently president and CEO of the International Crisis Group, a nonprofit organization which advises governments on means of avoiding armed conflicts. "Some people commit crimes under tremendous pressure. ... A smart sentencing policy leaves it to judges to decide."

Arbour also warns that the stiffened laws - particularly for relatively petty cannabis offences - may backfire by generating disrespect for drug control measures and promoting noncompliance. "When the laws are too harsh it's like a river hits the wall," she says.

When it comes to cannabis, Canadian legislation has long suffered from a "disconnect" with social realities, as polls show the vast majority of Canadians support decriminalization of marijuana, while legislators seem bent on introducing laws to prohibit its use,

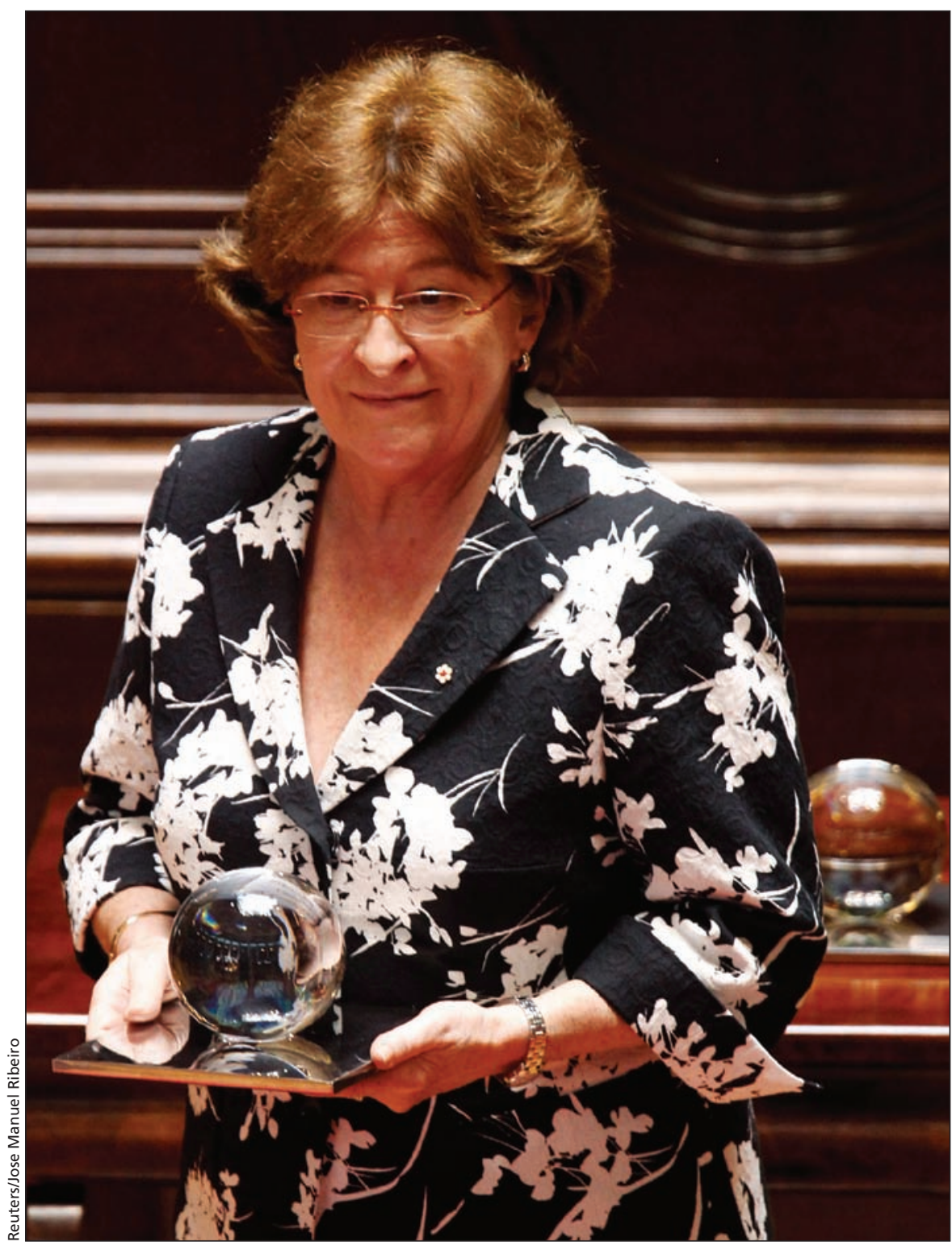

"When the laws are too harsh, it's like a river hits the wall," says former Supreme Court of Canada Justice Louise Arbour of Canada's new minimum sentences law for drug offenders.

says Arbour, who in 2003 wrote a dissenting Supreme Court opinion that argued imprisonment for marijuana use is not justified on the grounds that it constitutes a risk to public health, as the harm caused is only to the user, not others (http://scc.lexum.org/en/2003/2003 scc74/2003scc74.html).
"For the vast majority of recreational consumers the harm is minimal," Arbour insists.

Arbour's biting critique is part of a growing chorus of opposition to Bill C-10, which compels judges to impose sentences of at least one year in drug cases involving violence, repeat offend- 
ers or crime groups, and at least two years in drug cases involving persons under the age of 18. A minimum sixmonth sentence must be issued to those who grow five or more cannabis plants.

Among others who have assailed the legislation are three provincial officers of health, including British Columbia's Dr. Perry Kendall, who contended it is a "complete departure from evidence-based policy-making" that would clog jails and expose nonviolent drug offenders to health risks (www.openmedicine.ca/article/view /501/453).

Other critics have included former federal health minister Ujjal Dossanjh and three other former BC attorneysgeneral, who urged the federal government to "abandon mandatory minimum sentences for minor and non-violent marijuana-related offences and instead pursue a taxation and regulation strategy to better protect community health and safety while at the same time undermining gang profits" (http://stoptheviolencebc.org /2012/02/07/former-attorneys-general -endorse-stop-the-violence-bc/).

Under the aegis of the Global Commission on Drug Policy, Arbour and a blue-ribbon group of former world leaders and executives called on Prime Minister Stephen Harper to "adopt an evidence-based approach to controlling cannabis" and to "pursue a public health approach aimed also at undermining the root causes of organized crime" (http ://stoptheviolencebc.org/wp-content/up loads/2012/02/Stop-the-Violence-BC -Global-Commission-on-Drug-Policy -letter-Bill-C-10-Letter.pdf).

They also urged that marijuana be taxed and regulated under "a public health framework. ... This approach also has the potential to actually reduce rates of cannabis use while also generating significant tax revenue."

The Global Commission on Drug Policy has argued that "fundamental reforms in national and global drug control policies are urgently needed" as the global war on drugs has failed to curtail supply or consumption. "Repressive efforts directed at consumers impede public health measures to reduce HIV/AIDS, overdose fatalities and other harmful consequences of drug use. Government expenditures on futile supply reduction strategies and incarceration displace more cost-effective and evidence-based investments in demand and harm reduction," the commission stated in a report, War on Drugs (www.global commissionondrugs.org/wp-content/the mes/gcdp_v1/pdf/Global_Commission _Report_English.pdf).

Stop the Violence BC, a coalition of law enforcement officials, public health scientists and drug policy advocates, also urges reform of cannabis policies in order to reduce gang-related violence and other social harms. "Eighty percent of the revenue for organized crime in BC comes from marijuana," says coalition member Evan Wood, director of the Urban Health Research Initiative at the BC Centre for Excellence in HIV/AIDS.

Citing estimates from the Health Officers Council of BC, Wood also notes that 36 times more money is spent in Canada on drug law enforcement than on prevention and research, raising the question of whether a more "fiscally responsible" public health approach to drugs might be wiser (http://drugpolicy .ca/wp-content/uploads/2011/11/Regu lated-models-Final-Nov-2011-1.pdf). - Paul Christopher Webster, Toronto, Ont.

CMAJ 2012. DOI:10.1503/cmaj.109-4171 